\title{
Organizational learning and value creation in local governance: the mediating role of crowdsourcing
}

\author{
Regina Lenart-Gansiniec and Lukasz Sułkowski \\ Jagiellonian University in Krakow, Krakow, Poland
}

\begin{abstract}
Purpose - Different studies have analyzed the relationship between organizational learning and value creation. However, the question of how crowdsourcing affects the relationships between organizational learning and value creation remains unexplored. This paper aims to explore the mediating role of crowdsourcing in the relationship between organizational learning and value creation in local governance.

Design/methodology/approach - The hypotheses were tested based on data collected from 205 local governance units in Poland using crowdsourcing. Data collection was carried out by using a set of standardized questionnaires. Correlation analyses were used to specify the strength of the relationships between the variables. To test the hypotheses, multiple regression analysis was used.

Findings - The results have shown that in the local governance organizational learning is related to crowdsourcing, while organizational learning is not related to value creation. Crowdsourcing does not play a mediating role in explaining the relationship between organizational learning and value creation.

Research limitations/implications - A research model was developed based on the relevant literature in the field of organizational learning, value creation and crowdsourcing. This study urges researchers to explore the relationship between organizational learning and value creation in other public organizations using crowdsourcing.

Originality/value - This is the first study on the intermediate role of crowdsourcing in the relationship between organizational learning and value creation in local governance. The proposed model enriches the existing literature and allows better understanding of how crowdsourcing acts as an intermediary in the organizational learning-value creation relationship.
\end{abstract}

Keywords Organizational learning, Value creation, Crowdsourcing, Local governance

Paper type Research paper

\section{Introduction}

Contemporary public organizations are expected to react quickly to changes occurring in their dynamic and uncertain environment and to demonstrate openness, transparency and accountability to their clients, as well as to provide them with effective and high-quality services. The possibilities of meeting these expectations and challenges may be seen in

(c) Regina Lenart-Gansiniec and Łukasz Sułkowski. Published by Emerald Publishing Limited. This article is published under the Creative Commons Attribution (CC BY 4.0) licence. Anyone may reproduce, distribute, translate and create derivative works of this article (for both commercial and non-commercial purposes), subject to full attribution to the original publication and authors. The full terms of this licence may be seen at http://creativecommons.org/licences/by/4.0/legalcode

The authors would like to thank this Special Issue's Editor Nataša Rupčić and anonymous referees whose detailed constructive comments and suggestions helped to improve the paper.

This project was financed from the funds provided by the National Science Centre, Poland awarded on the basis of decision number DEC-2016/21/D/HS4/01791.
Mediating role of crowdsourcing

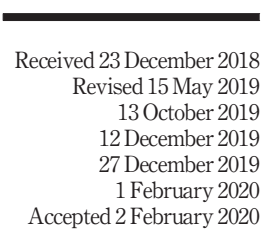

Accepted 2 February 2020

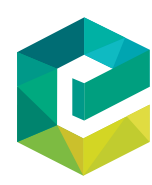

The Learning Organization Vol. 27 No. 4,2020 27 No. 4,2020
pp. $321-335$

Emerald Publishing Limited 0969-6474 DOI 10.1108/TLO-12-2018-0213 
knowledge, its configuration, organizational learning (Rashman et al., 2009) and its application in value creation (Pang et al., 2014).

Research on organizational learning in public organizations has been conducted intensively for over 15 years, and the number of publications devoted to this problem has been constantly growing. It is argued that organizational learning is a requirement for public sector organizations (Greiling and Halachmi, 2013), a paradigm and sine qua non condition of effective management (Rashman et al., 2009). Organizational learning allows public organizations to cope with challenges of modern times, in particular in the case of local self-governments (Olejarski et al., 2018). Despite the notably increased body of research on organisational learning in public organizations, it is interesting to note that the research results are still ambiguous and fragmented (Rashman et al., 2009), and many questions remain open. One of the questions refers to the role of organizational learning in the value creation in local governance. Looking at current research, this question does not provide a comprehensive answer. Research is limited to the commercial sector, which shows how organizational learning may help value creation (Sánchez et al., 2010). These studies confirmed that organizational learning contributes to the value-creation process and strengthens the organization's ability to create new ideas and methods to meet clients' needs. In addition, research showed impact of knowledge management on the value creation in Icelandic service companies (Edvardsson and Oskarssson, 2011).

Taking the concept of creating shared value (Porter and Kramer, 2011) as a theoretical framework to improve the quality of public organization services, enhance innovation and create value, it becomes clear that public organizations need the local community. Therefore, it is important to establish cooperation with stakeholders, especially citizens, and include them in problem solving, creating a shared vision and the establishment of collective goals. In this context, McNutt (2014, p. 60) suggests, "one of the more popular modes of Web 2.0 engagement is crowdsourcing, with a focus on the quantity of public input obtained".

Some studies have shown the importance of Web 2.0 solutions for creating value for citizens (Griffith and Wilding, 2008; Hui and Hayllar, 2010). Thanks to Web 2.0, citizens are no longer just users but also co-creators. Web 2.0-based tools allow citizens to participate in the process of evaluating, improving and designing of services. Hui and Hayllar (2010, p. 123) suggest that "having Web 2.0 tools available and being used more widely will help governments to better identify the collective public value while still enabling them to respond to individual preferences". Others have suggested that organizational learning is related to value creation (Van Dooren, 2011). In this case, organizational learning helps in refining and deepening existing knowledge, in defining existing knowledge stocks and in improving how they are used, which results in expanding or enriching their value creation (Kang et al., 2007) as well as building and developing portfolios of new services for clients. In short, organizational learning is a process that enables improvement and development of existing services and creation of new services.

However, research on the relationship between crowdsourcing, organizational learning and value creation is scarce (Osimo, 2008). Moreover, it is an important direction of research (Tucci et al., 2018), also in public organizations. Aitamurto and Chen (2017, p. 18) suggested that "future research should examine the value creation dimensions by studying knowledge creation, democratic aspects and economic value in several cases of crowdsourced policymaking”. First, crowdsourcing brings many advantages to public organizations including collecting information about the needs of citizens, acquiring ideas for problem solving, empowering citizens, strengthening legitimacy and enhancing effectiveness of public services and goods (Liu, 2017). Second, "public sector crowdsourcing is still in its infancy, having much less maturity than private sector crowdsourcing" (Loukis and Charalabidis, 2015, p. 5). In addition, current 
research on organizational learning suggests conducting further research in public organizations (Örtenblad, 2013), as well as in local governance (Rządca and Strumińska-Kutra, 2016). That is why we aim to fill the gap in this respect.

Therefore, the purpose of this study is to explore the mediating role of crowdsourcing in the relationship between organizational learning and value creation in local governance. Given the importance of organizational learning in stimulating value creation, we analyze and extend the findings by Sánchez et al. (2010). Sánchez et al. (2010) explored how organizational learning was linked to value creation (Sánchez et al., 2010) without taking crowdsourcing into account. We have developed a model that establishes the relationship between organizational learning, value creation and crowdsourcing in local governance.

Local governance in Poland was selected as the object of research. Local governance has been seen reaching for crowdsourcing in many European countries (Nemec and de Vries, 2012). In Poland, this tendency is also present. A recent review study shows that crowdsourcing is a popular concept in local governance (Haltofova, 2018). The importance of crowdsourcing in local governance in Poland was manifested in the Polish "National Urban Policy" in 2015 (Polish Ministry of Infrastructure and Development, 2015). To strengthen the citizens' involvement, local governance in Poland strives to implement crowdsourcing (Podgórniak-Krzykacz and Przywojska, 2019). In this context, crowdsourcing in local governance in Poland plays a very important role and is used to improve the citizens' participation in decision-making, quality of service delivery and performance (OECD, 2015). In addition, review of the current state of knowledge about crowdsourcing suggests conducting future research in local governance (Brabham, 2008). To our best knowledge, crowdsourcing in local governance in Poland has not yet been studied.

\section{Theoretical background and hypotheses development}

Organizational learning in local governance

In this study, organizational learning is defined as the "process of change in individual and shared thought and action, which is affected by and embedded in the institutions of the organization". In this approach, organizational learning is "the principal means of achieving strategic renewal of an enterprise" (Crossan et al., 1999).

Many scholars believe that organizational learning in public governance is underrepresented in public sector literature (Olejarski et al., 2018; Rashman et al., 2009; Siciliano, 2017). Rashman et al. (2009, p. 463) argue that "the concepts of organizational learning and knowledge are under researched in relation to the public sector". To date, a few empirical studies have examined organizational learning in public organizations. For example, Visser and Van der Togt (2016) proposed models for transforming a public organization into a learning organization. Barette et al. (2012) identified organizational learning facilitators for environmental situations and processes. Vince and Saleem (2004) explored the relationship between emotion, learning and organizing in the public organization. Yeo (2007) investigated the relationship between organizational learning and its impacts on public organizations. Tang and Yeh (2015) examined the relationships between organizational culture, leadership style and organizational learning in public organizations. Lauer and Wilkesmann (2017) studied the relationship between two modes of governance (transactional and transformational) and organizational learning. 
TLO

27,4

324

Organizational learning and value creation in local governance

According to Lepak et al. (2007, p. 181) value creation:

[...] refers to the specific quality of a new job, task, product or service as perceived by users in relation to their needs, such as the speed or quality of performance on a new task or the aesthetics or performance features of a new product or service.

Value creation may be divided into direct and indirect value creation (Sánchez et al., 2010). Direct value creation refers to improving quality of the offered products and services, whereas indirect value creation refers to introducing innovative services that are created with various stakeholders.

Value in local government means improved services to citizens (Bannister and Connolly, 2014; Cordella and Bonina, 2012), reacting by public organizations to the changing expectations of citizens, meeting the needs of citizens, increasing their satisfaction, obtaining legitimacy, improving the quality of public services (Osborne, 2018) and creating new, innovative solutions for citizens. Current literature contends that the development of organizational learning (Castaneda, 2018) plays a significant role in value creation (Sánchez et al., 2010). Organization resources allow for sustained competitive advantage, which drives value creation. In this case, organizational learning enables organizations to improve knowledge creation that is used to build and develop portfolios of new services for clients (Cuffa and Stell, 2019, p. 120). In short, organizational learning is a process that enables improvement, development of existing services and creation of new services.

Based on these arguments, it is expected that organizational learning may be important for the value creation in public organizations in terms of improving the quality of services offered to citizens (direct value creation) and regarding the creation of innovative solutions by public organizations with the participation of citizens (indirect value creation). Building on the aforementioned literature, the following hypotheses are suggested:

H1. Organizational learning positively affects value creation in local governance.

H1a. Organizational learning positively affects direct value creation in local governance.

H1b. Organizational learning positively affects indirect value creation in local governance.

\section{Organizational learning and crowdsourcing in local governance}

Crowdsourcing is defined as "an online, distributed problem-solving and production model" (Brabham, 2008). Through crowdsourcing, citizens bring resources to public organizations in the form of time, specialist knowledge and commitment, searching for new ideas and creating knowledge (Aitamurto and Chen, 2017). There are several reasons why organizational learning makes it easier for public organizations to reach for crowdsourcing. First, organizational learning facilitates implementation of innovations, particularly technological innovations (Devece et al., 2019). Crowdsourcing is considered a technological innovation that integrates the crowd into entrepreneurial activities (Brem et al, 2019). Secondly, for organizations to fully exploit the potential of crowdsourcing, they must have a variety of strategic assets and be supported by management and organizational skills. Implementation of crowdsourcing can be achieved if organizational learning is available. Hence, crowdsourcing and organizational learning are complementary (Schlagwein and Bjorn-Andersen, 2014). Therefore, in relationship between crowdsourcing and organizational learning, the following hypothesis can be stated:

H2. Organizational learning positively affects crowdsourcing in local governance. 
Crowdsourcing is helpful in identifying and understanding citizen's needs and preferences, acquiring innovative ideas, obtaining feedback from stakeholders and suggestions for improving existing services. Moreover, crowdsourcing ensures organizations to streamline and create new services and solutions ( $\mathrm{Xu}$ et al., 2015). Crowdsourcing is positively associated with generating service innovations and creating innovativeness of solutions.

Local governance units create value through interacting with life experiences and the societal context of a service user (Osborne, 2018). In the local governance context, crowdsourcing allows governments to involve citizens to create public services and design policies (Valle-Cruz, 2019) and ensures the possibility to create value for stakeholders. Based on the above analysis, we propose the following hypotheses:

H3. Crowdsourcing positively affects value creation in local governance.

$H 3 a$. Crowdsourcing positively affects direct value creation in local governance.

$H 3 b$. Crowdsourcing positively affects indirect value creation in local governance.

\section{The mediating role of crowdsourcing}

There is some evidence to support the viewpoint that crowdsourcing can be used by public organizations to increase the benefits of organizational learning for value creation in local governance. For example, Devece et al. (2019) suggested that positive relationship between market orientation and organizational performance is partially mediated by the use of crowdsourcing. In this context, learning organizations are able to reach for innovative crowdsourcing tools and do so to better respond to the needs of stakeholders (LenartGansiniec and Sulkowski, 2018). Xu et al. (2015) showed that implementation of crowdsourcing exerts an indirect impact by developing innovative competences. Cordella and Paletti (2018) described crowdsourcing in the light of value creation and also suggested characteristics of value creation in public organizations that meet the following conditions: production process is open and public organizations rely on internal and external resources. In summary, crowdsourcing enables acquisition of ideas from various stakeholders and therefore contributes to the development of new services (Devece et al., 2019). Based on these findings, the fourth hypothesis was developed as follows:

H4. Crowdsourcing mediates the relationship between organizational learning and value creation in local governance.

The research model, which is based on our hypotheses, is illustrated in Figure 1. The model tests the relationship between organizational learning and value creation and explores the mediating role of crowdsourcing in the relationship between organizational learning and value creation in local governance.

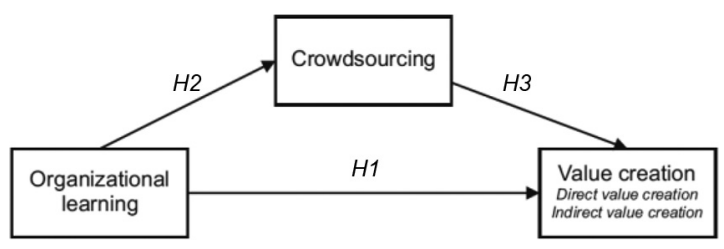

Figure 1. Research model 
TLO

27,4

326

\section{Research design}

Data collection and sample

Local governance units "have turned into more polycentric systems in which a variety of actors are engaged in local decision-making processes" (Rządca and Strumińska-Kutra, 2016, p. 916). Just recently, local governance units have started to attract attention of researchers interested in organizational learning (e.g. Rashman et al., 2019), value creation (e.g. Ryan, 2014) and crowdsourcing (e.g. Sumra and Bing, 2016), but they still remain outside the mainstream of the research focus (Cochrane, 2019). We focus, particularly, on municipal offices as among the very few research studies conducted in the local governance units, it is hard to find any studies exploring crowdsourcing of the municipal offices (Brabham, 2008). As stated by Haltofova (2018), crowdsourcing is a key tool for improving local governance units.

The data were collected between January 2018 and June 2018. Administration of the survey proceeded in two stages. First, we identified a total of 930 municipal offices in Poland. In Poland, there is no database of municipal offices that use crowdsourcing. To identify them, the questionnaire included the note that offices using crowdsourcing should also refer to questions about crowdsourcing. Second, we assumed that to reduce the error of non-response, which usually leads to common method bias, we conducted research in a mixed mode, i.e. using online surveys by using the forms posted on the Webankieta.pl website and questionnaires sent by e-mail. The type of data collection therefore depended on the choice the respondents made after being invited to participate in the research. We sent invitations to participate in the survey to all municipal offices in Poland. We informed them about the purpose of the study and potential benefits for those completing it, i.e. access to the study report after it has been completed. One of the major challenges for studies using surveys as a data collection method is the non-response bias, which is why we sent three reminders, one every two weeks.

The data collection was performed by using a questionnaire distributed among 930 local governments in Poland. We received 501 questionnaires. In total, the study involved 296 municipal offices that did not use crowdsourcing and 205 offices that have been using crowdsourcing. The study involved 279 municipal offices from cities of up to 20,000 inhabitants, 183 offices from cities from 20,000 to 100,000 inhabitants, 34 offices from cities from 100,000 to 500,000 inhabitants and 5 municipal offices from cities with over 500,000 inhabitants. The respondents in municipalities that do implement crowdsourcing included managers or employees directly involved in the implementation of crowdsourcing in the municipality. The survey involved 299 women and 202 men in managerial positions with a work experience of over 10 years, and having a university degree. The age of the respondents ranged from 41 to 50 years.

\section{Measurements}

The ensure content validity, we used scales that have been validated by researchers in various studies. All variables were measured on the five-point Likert scale ranging from 1 (strongly disagree) to 5 (strongly agree).

Organizational learning. Organizational learning was examined by using the Strategic Learning Assessment Map (SLAM) with 24 items adopted from Bontis et al. (2002). We used it in its original form. We chose SLAM to measure organizational learning for several reasons. First, the SLAM tool was developed by Bontis et al. (2002) with a high degree of rigor and then validated among 20 scientists members of the American Society for Training and Development and 1,924 employees. In addition, its correctness was also verified empirically among 480 respondents from 32 organizations. All elements of the questionnaire 
were tested and found to be reliable and appropriate. Second, SLAM has repeatedly demonstrated good value for research and management practice by revealing good reliability and factorial validity. It enables capturing the complexity and dynamics of learning in public organizations (Okwechime et al., 2018). Sample items are: "Individuals are able to break out of traditional mind-sets to see things in new and different ways", "We have effective conflict resolution when working in groups".

Crowdsourcing. To measure the use of crowdsourcing, we used a scale developed by $\mathrm{Xu}$ et al. (2015) and verified by Devece et al. (2019). We adapted scale to the public organization context, in particular we replaced the word "firm" to "our organization" (Items 2, 3, 5, 7 and 8), and we removed the word "product" (Items 1, 3 and 7). The basic premise for choosing this scale is that it is based on the fact that clients are a valuable source of knowledge and organizations motivate them through crowdsourcing to participate in generating creative ideas. The scale includes eight items. Sample items are: "The organization has introduced platforms to develop ideas about new services", "There are knowledge transfer systems to disseminate the best ideas".

Value creation. There is no widely accepted scale for measuring value creation and not many efforts have been made in this regard. In choosing the tool, we were guided by the following important premises: simplicity, the possibility of quantitative analysis, functionality, diversity of perception and the desire to maintain the continuity of the analysis and research conducted by Sánchez et al. (2010). As a point of reference, the scale of Sánchez et al. (2010) was applied. The original scale had to be modified based on the theoretical contribution from the literature and discussions with public managers during the pretesting phase of the scale development. Eight items were used to measure direct value creation in the context of local governance including:

(1) responding to client expectations;

(2) client satisfaction;

(3) client loyalty;

(4) client trust;

(5) relations with the client;

(6) service availability;

(7) punctuality in dealing with client matters; and

(8) communication with client.

We used nine items to assess indirect value creation in the context of local governance including:

(1) suggestions of client about how to improve or develop services;

(2) looked ideas about new services;

(3) participation of clients in joint projects;

(4) testing of prototypes new services;

(5) knowledge of possible client needs;

(6) responding to client needs;

(7) information on organizations;

(8) information on market trends; and

(9) information on possible competitors. 
TLO

27,4

328

\section{Results and analysis}

Reliability and validity analysis

Value creation may depend on the industry (Sumbal et al., 2019), and the adopted scale has not been used in the context of public organizations. Before hypotheses testing, we performed exploratory factor analysis (EFA) to measure construct validity (Hair et al., 2006). The main components analysis and Promax rotation were used, because we assumed possible correlations between the factors. As a result, we received a one-factor solution for value creation, explaining $44.41 \%$ of the total variance and achieving an acceptable level of adequacy of sampling, KMO 0.911. The original factor solution (Sánchez et al., 2010) turned out to be inaccurate in the case of municipal offices in Poland, because the loadings were in a different configuration than in the case of manufacturing companies located in Spain. In addition, taking into account the acceptable level of satisfactory factor loading set at 0.6 (Fornell and Larcker, 1981), the following four elements were removed from the study: "responding to client expectations", "client trust", "testing of prototypes new services" and "information on possible competitors".

Second, we assessed accuracy and reliability of the questionnaire by calculating the Cronbach's alpha coefficient. The results show that all Cronbach's alpha values exceeded 0.70 , which indicates high reliability and consistency of the scales and measures (Lance et al., 2006). Two factors of the value creation solution were tested for internal consistency. Cronbach's alpha for value creation measured by 13 items in two dimensions is acceptable because it reached 0.918 (Lance et al., 2006). In more detail, Cronbach's alpha is acceptable for the first $(\alpha=0.851)$ and second $(\alpha=0.881)$ factor. Cronbach's alpha for crowdsourcing measured by eight points is acceptable: $\alpha=0.884$. Cronbach's alpha for customer value creation measured by 13 points is acceptable: $\alpha=0.847$ and Cronbach's alpha for organizational leaning measured by 24 points is acceptable: $\alpha=0.972$. The scale used consists of positively worded questions, which may bring the risk of common method bias (CMB) (Podsakoff et al., 2003). To identify this effect, we estimated the level of common method variance by using Harman's single factor test. The results showed no common bias in the findings. Using the raw data, we confirmed that there is no risk of $\mathrm{CMB}$ as the factor with the highest eigenvector identified using unrotated factor analysis explains only $35.3 \%$ of the total variance.

\section{Hypothesis testing}

To describe relationships between organizational learning and value creation, the significance test of Spearman's rank correlation (rs) was applied. Regression was used to check whether and to what extent organizational learning depends on crowdsourcing maturity. All calculations and statistical analyses with regard to quantitative data were made by using the following programs: IBM SPSS Statistica 25 and Statistica 12. Calculations were made on the basis of averages, because the study adopted a multipart approach for the considered variables (Rovai et al., 2014). We conducted the analysis of the mediation effect by using the fourth regression model with the PROCESS macro in SPSS 25 (Model 4) (Hayes, 2013).

Correlation analysis. As a first step, we ran correlations between organizational learning, value creation and crowdsourcing. We explored both direct and indirect value. To this end, the Spearman rank correlation coefficient was applied. Attention is paid to the values of the $p$-level, because this will allow the credibility of the obtained result to be determined (Table 1).

The correlation matrix shows that organizational learning is correlated with crowdsourcing, while organizational learning and crowdsourcing are not correlated with value creation. More specifically, organizational learning does not correlate with direct and indirect value creation, and further crowdsourcing does not correlate with value creation, direct and indirect value creation. 
Regression analysis. To investigate the potential causal relationships between variables, we performed multiple regression analysis (Table 2). We developed seven models (M1-M7) to analyze the impact of an independent variable on each of the dependent variables. Models 1-3 (M1-M3) were used as basic models to examine the impact of organizational learning on value creation, as well as organizational learning on direct and indirect value creation.

As for $H 1$, based on the results obtained, we can see a weak relationship between organizational learning and value creation $(\beta=0.050, p<0.001)$, as the correlation is not statistically significant. Therefore, $H 1$ is not supported. In addition, we did not find a statistically significant relationship between organizational learning and direct value creation $(\beta=0.053, p>0.05)$. Thus, $H 1 a$ is not supported. The results indicate no statistically significant relationship between organizational learning and indirect value creation ( $\beta=0.028, p>0.05$ ); therefore, $H 1 b$ is not supported.

Model 4 (M4) was used to assess the relationship between organizational learning and crowdsourcing. The results indicate a statistically significant relationship between organizational learning and crowdsourcing $(\beta=0.374, p<0.05)$; therefore, $H 2$ is supported.

Models 5-7 (M5-M7) were used to assess the importance of crowdsourcing for value creation, including direct and indirect value creation. Based on the results, crowdsourcing is negatively related to value creation $(\beta=-0.005, p>0.05)$; therefore, $H 3$ is not supported. As for $H 3 a$, the results indicate that crowdsourcing is not significant for direct value creation $(\beta=0.034, p>0.05)$; therefore. $H 3 a$ is not supported. As for the relationship between crowdsourcing and indirect value creation, it is negative $(\beta=-0.019, p>0.05)$, which is why $H 3 b$ is not supported.

To sum up, among the seven prepared models of single-variable regression, the fourth model, in which crowdsourcing is the explanatory variable for organizational learning has the best match, and thus the highest explanatory power $[\mathrm{F}(32.960)=18.661 ; p<0.01$; beta $=0.374]$ ). This model explains $14 \%$ of the organizational learning variance. The determination coefficient $\left(R^{2}\right)$ was 0.140 . Interestingly, organizational learning seems to be the least important factor for value creation either direct or indirect.

Mediation analysis. We performed the PROCESS macro bootstrapping method to analyze the proposed mediating role (Hayes, 2013). By resampling 5,000 times, it was found that the bootstrapping method findings were in support of the regression analyses (Preacher and Hayes, 2004). The use of bootstrapping, rather than Sobel, Aroian and Goodman tests, allows more precise estimation of indirect effects in variable analysis. The obtained results do not support the assumptions contained in H4. Crowdsourcing does not affect the relationships between organizational learning and value creation in local governance $(\beta=-0.0118 ; p>0.05 ; 95 \% \mathrm{CI}=[-0.1147 ; 0.0910]$. Thus, $H 4$ is not supported.

\begin{tabular}{|c|c|c|c|c|c|c|c|c|}
\hline No. & Variable & Mean & $\mathrm{SD}$ & 1 & 2 & 3 & 4 & 5 \\
\hline 1 & Organizational learning & 3.88 & 0.74 & 1.000 & & & & \\
\hline 2 & Crowdsourcing & 3.42 & 0.97 & $0.346 * *$ & & & & \\
\hline 3 & Value creation & 3.91 & 0.50 & 0.063 & 0.043 & & & \\
\hline 4 & Direct value creation & 3.84 & 0.63 & 0.043 & 0.029 & $0.737 * *$ & & \\
\hline 5 & Indirect value creation & 3.97 & 0.65 & 0.064 & 0.032 & $0.810 * *$ & $0.263^{* *}$ & 1.000 \\
\hline
\end{tabular}

Notes: ${ }^{* *} p<0.01$ (two-tailed) was considered as the level of significance; $* p<0.05$ (two-tailed) was considered as the level of significance; $N=205$

Table 1. Correlations 


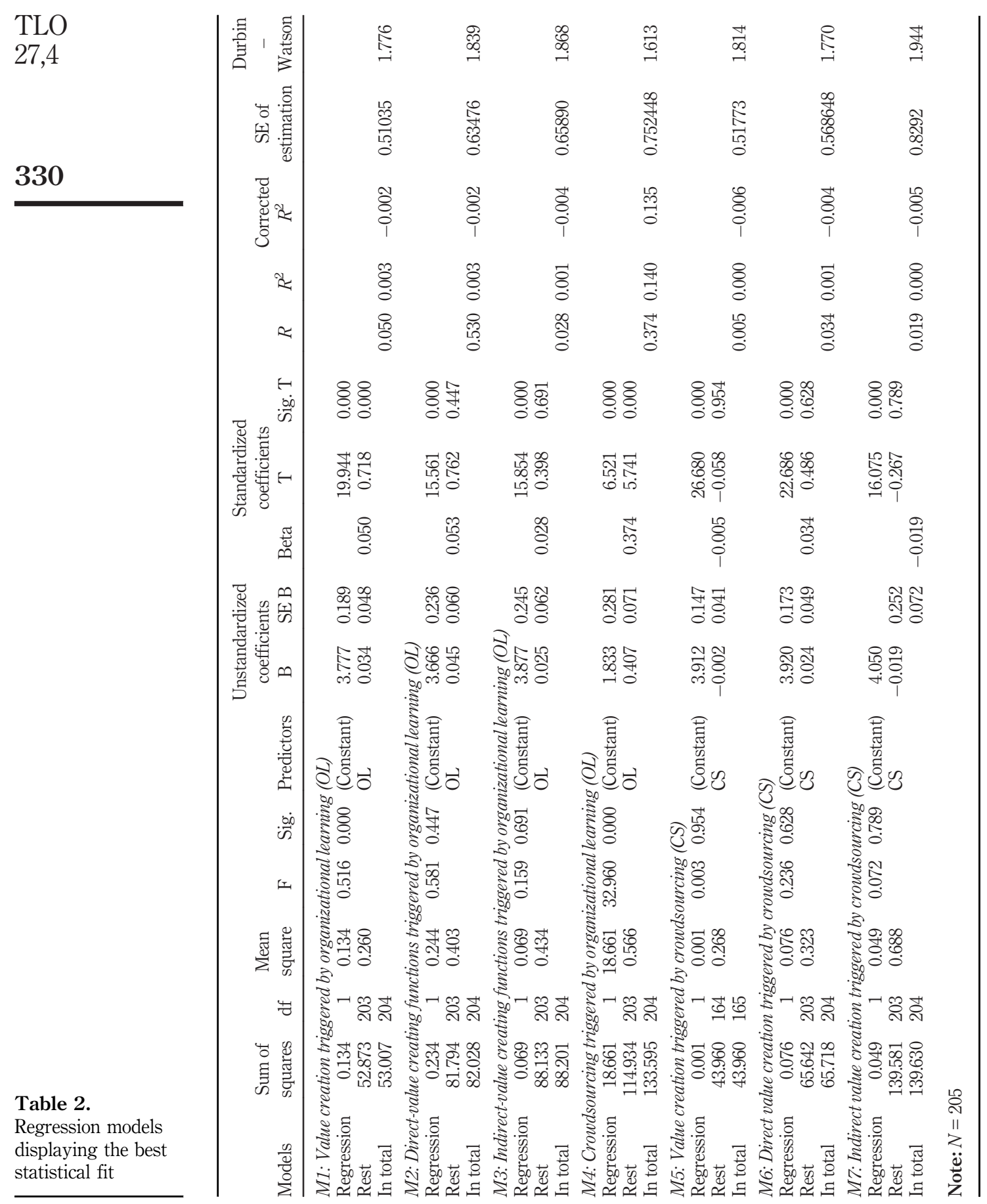




\section{Discussion}

The aim of this study was to explore the mediating role of crowdsourcing in the relationship between organizational learning and value creation in local governance. We conducted the research in local governance units in Poland, in accordance with the recommendations provided by Nemec and de Vries (2012). Some previous studies have highlighted the positive impact of organizational learning on value creation (Sánchez et al., 2010) and the impact of knowledge management on the value creation (Edvardsson and Oskarssson, 2011). This study contributes to this literature by providing evidence for public organizations.

First, relationship between organizational learning and value creation in local governance $(H 1, H 1 a, H 1 b)$ was tested through multiple regression analysis. It was found that there was no significant effect of organizational learning on value creation. Organizational learning was not found to be statistically significant for neither direct nor indirect value creation. Earlier empirical studies pointed out that organizational learning was affected by value creation (Sánchez et al., 2010; Kang et al., 2007). Our results do not support those findings. The results obtained may be explained by the specificity of public organizations. Value creation in the public organization needs specific processes, inputs, policies, programs and activities. The literature suggests that:

[...] to produce value, public officials must consider the entire 'value chain'. The value chain starts with inputs and moves to the production processes (for example, policies, programs and activities) used to transform inputs into outputs, which then affect a client (for example, a citizen or beneficiary), which leads to the social outcome that was the intended aim of the activity (Yotawut, 2018, p. 169).

Second, multiple regression analysis was applied to analyze $H 2$. The results revealed that organizational learning positively affected crowdsourcing in local governance. In this context, by organizational learning, local governance units can maintain relationships with their environment, respond quickly to stakeholders demands and increase innovation adoption (Devece et al., 2019). Earlier studies pointed out that crowdsourcing was affected by organizational learning (Alegre and Chivab, 2008; Feller et al., 2012). There is no study found in the relevant literature that explored the relationship between organizational learning and crowdsourcing in local governance. In this context, our research is first.

Third, the results of multiple regression analysis do not support the relationship between crowdsourcing and value creation $(H 3, H 3 a, H 3 b)$. Previous studies suggested that "citizens did not trust municipal e-governments and the value generated by governments was not enough, despite the efforts for delivering digital services" (Valle-Cruz, 2019, p. 15). Crowdsourcing must be effectively managed to obtain good results (Devece et al., 2019). However, crowdsourcing needs a combination of technological, motivational and managerial capabilities (Devece et al., 2019).

Four, Hayes (2013) mediation test was applied to analyze $H 4$. The results revealed that crowdsourcing did not mediate the relationship between organizational learning and value creation in local governance. This may be due to the fact that crowdsourcing is indicated as a phenomenon triggered by many different factors (Devece et al., 2019).

\section{Conclusion}

Overall, our study provides insight into crowdsourcing with respect to organizational learning and value creation. Drawing on creating shared value concept, this study is a contribution to current literature in three ways. First, this work introduces and tests a model that explores the nature of the relationship between organizational learning and value
Mediating role of crowdsourcing 
creation including testing the intermediary role of crowdsourcing in this relationship in the context of local governance.

Previous studies tested the relationship between organizational learning and value creation in the context of manufacturing companies taking into account market turbulence (Sánchez et al., 2010).

We introduced crowdsourcing because crowdsourcing research in local governance is postulated as important and necessary (Brabham, 2008). Previous results suggest that crowdsourcing may limit innovations (Majchrzak and Malhotra, 2013), hinder improvement and development of services (Mergel, 2018) and drain resources from professional administrative work. The literature suggested that to obtain potential benefits from crowdsourcing and counteract against threats, public organizations need to design effective incentives to services, aggregating an overwhelming amount of input from citizens, evaluating the outcomes (Nam, 2012) and creating a legal framework to ensure the accountability of the responsible agencies as well as the privacy and rights of citizens (Liu, 2017). It is only then that local governance can determine whether the knowledge acquired through crowdsourcing contributes to creating value, in particular to streamlining processes and services, providing them in a more efficient and cost-effective manner, as well as creating innovative solutions for citizens.

This study has some limitations. The sample drawn for this study comes from a population of local governance in Poland. Moreover, considering the fact that value creation depends on the sector (Sánchez et al., 2010), our intentional choice is theoretically justified. Potentially, future studies could be conducted with regard to other public organizations using crowdsourcing. Our sample was limited to one developing country, but studies can be carried out in other countries, especially in Central and Eastern Europe. Overall, the selfadministered questionnaires and the subjective measurement of the variables were subject to bias. To identify this effect, the level of common variance of the method was estimated by using Harman's single factor test. We can conclude that in the presented research there was no error of common method variance. The process of data collection was based on obtaining opinion from the respondents, which could affect the quality and shape of the conclusions drawn. In addition, there is a risk of excessive optimism regarding the occurrence of unconscious interference resulting from a tendency to provide similar answers to the questions included in the questionnaire. However, the questionnaire survey is widely used in management sciences and is an effective way of collecting data because it allows for generating larger samples of respondents and can be used for any statistical analysis. Future studies should make greater efforts to obtain objective indicators to improve the quality of measurements.

\section{References}

Aitamurto, T. and Chen, K. (2017), "The value of crowdsourcing in public policymaking: epistemic, democratic and economic value", The Theory and Practice of Legislation, Vol. 5 No. 1, pp. 55-72.

Alegre, J. and Chivab, R. (2008), "Assessing the impact of organizational learning capability on product innovation performance: an empirical test", Technovation, Vol. 28 No. 6, pp. 315-326.

Bannister, F. and Connolly, R. (2014), "ICT, public values and transformative government: a framework and programme for research", Government Information Quarterly, Vol. 31 No. 1, pp. 119-128.

Barette, J., Lemyre, L., Corneil, W. and Beauregard, N. (2012), "Organizational learning facilitators in the Canadian public sector", International Journal of Public Administration, Vol. 35 No. 2, pp. 137-149. 
Bontis, N., Crossan, M.M. and Hulland, J. (2002), "Managing and organizational learning system by aligning stocks and flows", Journal of Management Studies, Vol. 39 No. 4, pp. 437-469.

Brabham, D.C. (2008), "Crowdsourcing as a model for problem solving: an introduction and cases", Covergence, Vol. 1 No. 14, pp. 75-90.

Brem, A., Bilgram, V. and Marchuk, A. (2019), "How crowdfunding platforms change the nature of user innovation - from problem solving to entrepreneurship", Technological Forecasting and Social Change, Vol. 144, pp. 348-360.

Cordella, A. and Bonina, C.M. (2012), "A public value perspective for ICT enabled public sector reforms: a theoretical reflection", Government Information Quarterly, Vol. 29 No. 4, pp. 512-520.

Cordella, A. and Paletti, A. (2018), "ICTs and value creation in public sector: manufacturing logic vs service logic", Information Polity, Vol. 23 No. 2, pp. 125-141.

Crossan, M.M., Lane, H.W. and White, R.E. (1999), "An organizational learning framework: from intuition to institution", Academy of Management Review, Vol. 24 No. 3, pp. 522-537.

Cuffa, D. and Stell, A.V. (2019), "Organizational learning in public organizations: an integrative review", Navus - Revista de Gestão e Tecnologia, Vol. 9 No. 3, pp. 112-123.

Devece, C., Palacios, D. and Ribeiro-Navarrete, B. (2019), "The effectiveness of crowdsourcing in knowledge-based industries: the moderating role of transformational leadership and organisational learning”, Economic Research-Ekonomska Istraživanja, Vol. 32 No. 1, pp. 335-351.

Edvardsson, I.R. and Oskarssson, G. (2011), "Knowledge management and value creation in service firms", Measuring Business Excellence, Vol. 15 No. 4, pp. 7-15.

Feller, J., Finnegan, P., Hayes, J. and O'Reilly, P. (2012), "Orchestrating sustainable crowdsourcing: a characterization of solver brokerages", The Journal of Strategic Information Systems, Vol. 21 No. 3, pp. 216-232.

Fornell, C. and Larcker, D.F. (1981), "Evaluating structural equation models with unobservable variables and measurement error", Journal of Marketing Research, Vol. 18 No. 1, pp. 39-50.

Greiling, D. and Halachmi, A. (2013), "Accountability and organizational learning in the public sector public", Performance and Management Review, Vol. 36 No. 3, pp. 43-52.

Griffith, M. and Wilding, K. (2008), "ICT foresight: how ICT is shaping the future design and delivery of public services”, available at: www.icthub.org.uk/publications/ICT_Foresight.pdf (accessed 3 January 2020).

Hair, J.F., Jr., Black, W.C., Babin, B.J., Anderson, R.E. and Tatham, R.L. (2006), Multivariant Data Analysis, Pearson International Edition, NJ.

Haltofova, B. (2018), "Using crowdsourcing to support civic engagement in strategic urban development planning: a case study of ostrava, Czech Republic", Journal of Competitiveness, Vol. 10 No. 2, pp. 85-103.

Hayes, A.F. (2013), Methodology in the Social Sciences. Introduction to Mediation, Moderation, and Conditional Process Analysis: A Regression-Based Approach, Guilford Press, New York, NY.

Hui, G. and Hayllar, M.R. (2010), "Creating public value in e-government: a public-private-citizen collaboration framework in web 2.0", Australian Journal of Public Administration, Vol. 69 No. 1, pp. 120-131.

Kang, S.C., Morris, S.S. and Snell, S.A. (2007), "Relational archetypes, organizational learning, and value creation: extending the human resource architecture", Academy of Management Review, Vol. 32 No. 1, pp. 236-256.

Lance, C.E., Butts, M.M. and Michels, L.C. (2006), "The sources of four commonly reported cutoff criteria. What did they really say?", Organizational Research Methods, Vol. 9 No. 2, pp. 202-220.

Lauer, S. and Wilkesmann, U. (2017), "The governance of organizational learning: empirical evidence from best-practice universities in Germany", The Learning Organization, Vol. 24 No. 5, pp. 266-277. 
Lenart-Gansiniec, R. and Sułkowski, Ł. (2018), "Crowdsourcing - a new paradigm of organizational learning of public organizations", Sustainability, Vol. 10 No. 10, pp. 1-14.

Lepak, D.P., Smith, K.G. and Taylor, M.S. (2007), "Value creation and value capture: a multilevel perspective", Academy of Management Review, Vol. 32 No. 1, pp. 180-194.

Liu, H.K. (2017), "Crowdsourcing government: lessons from multiple disciplines", Public Administration Review, Vol. 77 No. 5, pp. 656-667.

Loukis, E. and Charalabidis, Y. (2015), "Active and passive crowdsourcing in government", in Janssen, M., Wimmer, M. and Deljoo, A. (Eds), Policy Practice and Digital Science. Integrating Complex Systems, Social Simulation and Public Administration in Policy Research, Springer, Cham, pp. 261-289.

McNutt, K. (2014), "Public engagement in the web 2.0 era: social collaborative technologies in a public sector context", Canadian Public Administration, Vol. 57 No. 1, pp. 49-70.

Majchrzak, A. and Malhotra, A. (2013), "Towards an information systems perspective and research agenda on crowdsourcing for innovation”, The Journal of Strategic Information Systems, Vol. 22 No. 4, pp. 257-268.

Mergel, I. (2018), "Open innovation in the public sector: drivers and barriers for the adoption of challenge.gov", Public Management Review, Vol. 20 No. 5, pp. 726-745.

Ministry of Infrastructure and Development (2015), "National urban policy 2023", available at: www. gov.pl/attachment/e8c39de7-a900-4052-b89a-53b0c4af8e75 (accessed 3 January 2020).

Nam, T. (2012), "Suggesting frameworks of citizen-sourcing via government 2.0", Government Information Quarterly, Vol. 29 No. 1, pp. 12-20.

Nemec, J. and de Vries, M. (2012), Public Sector Dynamics in Central and Eastern Europe, NISPAcee Press, Bratislava.

OECD (2015), "Open government data reviews unlocking the value of government data", available at: http://read.oecd-ilibrary.org/governance/open-government-data-review-of-poland_9789264241787en\#page1 (accessed 3 January 2020).

Okwechime, E., Duncan, P. and Edgar, D. (2018), "Big data and smart cities: a public sector organizational learning perspective", Information Systems and e-Business Management, Vol. 16 No. 3, pp. 601-625.

Olejarski, A.M.O., Potter, M. and Morrison, R.L. (2018), "Organizational learning in the public sector: culture", Public Integrity, Vol. 21 No. 1, pp. 1-17.

Örtenblad, A. (Ed.) (2013), Handbook of Research on the Learning Organization. Adaptation and Context, Edward Elgar, Cheltenham.

Osborne, S.P. (2018), "From public service-dominant logic to public service logic: are public service organizations capable of co-production and value co-creation?", Public Management Review, Vol. 20 No. 2, pp. 225-231.

Osimo, D. (2008), "Web 2.0 in government: why and how?", available at: http://ipts.jrc.ec.europa.eu/ publications/pub.cfm?id=1565 (accessed 10 September 2019).

Pang, M.S., Lee, G. and DeLone, W.H. (2014), "IT resources, organizational capabilities, and value creation in public sector organisations: a public-value management perspective", Journal of Information Technology, Vol. 29 No. 3, pp. 187-205.

Podgórniak-Krzykacz, A. and Przywojska, J. (2019), "The challenges of local development and priorities of mayors and presidents of polish cities - convergence or dissonance?", Optimum Economic Studies, Vol. 4 No. 4, pp. 121-133.

Podsakoff, P.M., MacKenzie, S.B., Lee, J.-Y. and Podsakoff, N.P. (2003), "Common method biases in behavioral research: a critical review of the literature and recommended remedies", Journal of Applied Psychology, Vol. 88 No. 5, pp. 879-903.

Porter, M. and Kramer, M. (2011), "Creating shared value”, Harvard Business Review, November/ December, pp. 62-77. 
Preacher, K.J. and Hayes, A.F. (2004), "SPSS and SAS procedures for estimating indirect effects in simple mediation models", Behavior Research Methods, Instruments, and Computers, Vol. 36 No. 4, pp. 717-731.

Rashman, L., Withers, E. and Hartley, J. (2009), "Organizational learning and knowledge in public service organizations: a systematic review of the literature", International Journal of Management Reviews, Vol. 11 No. 4, pp. 463-494.

Rovai, A.P., Baker, J.D. and Ponton, M.K. (2014), Social Science Research Design and Statistics, Watertree Press LLC, Chesapeake, VA.

Rządca, R. and Strumińska-Kutra, M. (2016), "Local governance and learning: in search of a conceptual framework", Local Government Studies, Vol. 42 No. 6, pp. 916-937.

Sánchez, J., Ángel, L., Santos-Vijande, M.L. and Trespalacios, J.A. (2010), "Organisational learning and value creation in business markets”, European Journal of Marketing, Vol. 44 Nos 11/12, pp. 1612-1641.

Schlagwein, D. and Bjørn-Andersen, N. (2014), "Organizational learning with crowdsourcing: the revelatory case of LEGO", Journal of the Association for Information Systems, Vol. 15 No. 11, pp. 754-778.

Siciliano, M.D. (2017), "Ignoring the experts: networks and organizational learning in the public sector", Journal of Public Administration Research and Theory, Vol. 27 No. 1, pp. 104-119.

Sumbal, M., Tsui, E., Irfan, I., Shujahat, M., Mosconi, E. and Ali, M. (2019), "Value creation through big data application process management: the case of the oil and gas industry", Journal of Knowledge Management, Vol. 23 No. 8, pp. 1566-1585.

Tang, L.L. and Yeh, Y.L. (2015), "Effect of organizational culture, leadership style, and organizational learning on organizational innovation in the public sector", Journal of Quality, Vol. 22 No. 5, pp. 461-481.

Tucci, C.L., Afuah, A. and Viscusi, G. (Ed) (2018), Creating and Capturing Value through Crowdsourcing, Oxford University Press, Oxford, pp. 39-57.

Valle-Cruz, D. (2019), "Public value of e-government services through emerging technologies", International Journal of Public Sector Management, Vol. 32 No. 5, pp. 530-545.

Van Dooren, W. (2011), "Better performance management", Public Performance and Management Review, Vol. 34 No. 3, pp. 421-434.

Vince, R. and Saleem, T. (2004), "The impact of caution and blame on organizational learning", Management Learning, Vol. 35 No. 2, pp. 131-152.

Visser, M. and Van der Togt, K. (2016), "Learning in public sector organizations: a theory of action approach", Public Organization Review, Vol. 16 No. 2, pp. 235-249.

Xu, Y., Enrique Ribeiro-Soriano, D. and Gonzalez-Garcia, J. (2015), "Crowdsourcing, innovation and firm performance", Management Decision, Vol. 53 No. 6, pp. 1158-1169.

Yeo, R.K. (2007), "Organizational learning in representative Singapore public organizations: a study of its contribution to the understanding of management in Singapore", International Journal of Public Sector Management, Vol. 20 No. 5, pp. 345-365.

Yotawut, M. (2018), "Examining progress in research on public value", Kasetsart Journal of Social Sciences, Vol. 39 No. 1, pp. 168-173.

\section{Corresponding author}

Regina Lenart-Gansiniec can be contacted at: regina.lenart-gansiniec@uj.edu.pl

For instructions on how to order reprints of this article, please visit our website:

www.emeraldgrouppublishing.com/licensing/reprints.htm

Or contact us for further details: permissions@emeraldinsight.com 